\title{
ALEJANDRO AMENÁBAR. EL ALUMNO QUE QUISO SUPERAR A SUS MAESTROS
}

\section{ALEJANDRO AMENÁBAR. THE STUDENT THAT WANTED TO OVERCOME THEIR TEACHERS}

\begin{abstract}
AUTORA
Graciela Padilla

Becaria FPU (Facultad de Ciencias de la Información, Universidad Complutense de Madrid). elcorreodegraci@hotmail.com
\end{abstract}

\section{RESUMEN}

Enfrentarse al estilo de cualquier director de cine es una tarea realmente difícil. Cada uno de ellos tiene un estilo propio. Si son grandes profesionales y artistas, ese estilo será inconfundible. El reto de analizar la trayectoria y el estilo de Alejandro Amenábar hace que ese desafío sea, si puede, más dificultoso. Se trata de un director muy joven, prodigiosamente precoz y a pesar de haber firmado sólo cuatro películas, muchos ya le llaman autor y creador. El peligro está en consagrarle inmediatamente o dejar que siga definiendo su estilo, porque todavía, para bien o para mal, le queda mucho que decir en el mundo del celuloide. A pesar de ello, este estudio intentará desentramar, en la medida de la posible, esa manera de hacer cine, que ya ha pasado de la etapa de despuntar hacia la fase de asentamiento.

\section{PALABRAS CLAVE}

Amenábar - Dirección de cine - Director precoz - Tesis. 


\section{ABSTRACT}

Facing the style of any movie director is a challenging task. Each has its own style. If they are great professionals and artists, the style is unmistakable. The challenge of analyzing the history and style of Alejandro Amenábar makes that challenge is, if possible, more difficult. This is a very young director, prodigiously early; despite having signed only four films, many now call him author and creator. Danger lies in devoting immediately or allowed to define his style, because he still, for better or for worse, has much to say in the movies world. However, this study will try to unravel, to the extent possible, that way of filmmaking, which has already passed the stage of dawn to the stage of settlement.

\section{KEY WORDS}

Amenábar - Film Direction - Early director - Tesis.

\section{ÍNDICE}

1. Introducción.

2. Breve retrato biográfico.

3. Análisis del cine de Amenábar.

4. Amenábar como guionista.

5. Del suspense al drama. Los géneros en Amenábar.

6. La cámara de Amenábar. Encuadres, angulaciones, fuera de campo.

7. Sentido del ritmo y dosificación de la información.

8. Sentido del tiempo. Secuencias y escenas. Formas de paso y recursos temporales.

9. La música y el silencio: la banda sonora. Amenábar como músico.

10. Fotografía. Uso de la luz y cromatismo.

11. Personajes. Estereotipos, individuos similares. De director a psicoanalista.

12. Influencias y conclusiones.

13. Bibliografía. 


\section{Introducción}

Mar adentro supuso, aparentemente, un cambio radical en la filmografía de Alejandro Amenábar. El estreno de este filme hizo que surgieran muchas dudas. ¿Era un nuevo cine de Amenábar?, ¿un cambio de registro? ¿Era algo que deseaba haber contado desde el principio, desde sus tiempos universitarios? ¿Una muestra de genialidad?, ¿o una demostración orgullosa de que sabe contar cualquier historia? Ahí estaban las dudas y las complicaciones: en caminar desde la mirada asustada de Ángela en Tesis, hasta el gesto cansado de Ramón en Mar adentro, percibiendo cómo la cámara había aprendido a moverse y a reflejar sentimientos tan dispares.

A simple vista, muy pocos se atrevían a explicar si hay algo que una a esas películas. No había obras especializadas que se aventuraran a desvelar el misterio. Ni siquiera el mismo Amenábar se había manifestado claramente al respecto. La respuesta objetiva se dará en las siguientes páginas e intentará acercarse a la mente del autor lo más posible. Sin embargo, el instinto de un virtuoso es un lugar insondable; demasiado complicado para ser explicado en unas páginas e inmoderadamente desordenado para ser entendido siquiera por su dueño. Sea como fuere, y hasta que un invento sea capaz de introducirse en Amenábar, hoy puede presumir de éxito de taquilla, público y crítica, con un Oscar a la Mejor Película Extranjera. No sabemos cómo será el futuro. Mas con lo conseguido hasta ahora, ya forma parte de la historia del cine español.

\section{Breve retrato biográfico}

Antes de comenzar el análisis, y tras haber leído algunas obras sobre Alejandro Amenábar, es conveniente relatar a grandes rasgos algunos episodios de su vida, por la influencia que tuvieron en su obra. Presume siempre de su nacionalidad chilena. Santiago de Chile fue la ciudad donde vino al mundo en 1972. El gobierno de Salvador Allende empezaba a encontrar demasiados enemigos y antes del golpe de 
Estado, la familia se trasladó a España, país donde había nacido la madre del cineasta. Alejandro tenía entonces un año y medio. Pasó su infancia en Paracuellos del J arama. Apenas salía a la calle después del colegio. Desde su casa, alimentaba su imaginación leyendo cuentos de misterio, dibujando y desarrollando una gran timidez e introversión. Al mismo tiempo, vivió muchos miedos infantiles. Todos esos miedos le inspirarían en el futuro para crear el mundo de Los otros.

El amor por el cine llegaría algo más tarde. Sus padres apenas les permitían, a él y su hermano mayor, ver la televisión. Amenábar sólo recuerda algunas series infantiles. Aunque unos vecinos de origen americano (Herbert Smith e Isabel Esquetino) le invitaban, cada fin de semana, a pequeñas proyecciones. Así conoció las películas que influirían en su filmografía: Al final de la escalera o Henry, retrato de un asesino. $Y$ unida a esa pasión por el cine, nacería otro entusiasmo por la música. Nunca acudió a clases de armonía, solfeo o composición. Sin embargo, la melodía se convertiría en otro mundo en el que poder desarrollar sus dotes artísticas.

Todas esas experiencias le llevaron a saber con claridad que estudiaría Ciencias de la Información. Acabado el Bachillerato, ingresó en la Universidad Complutense de Madrid. Recuerda que, en el primer curso, daban clase en el pasillo, porque no disponían de aulas suficientes. Poco a poco, las cambió por la cafetería y en cuarto curso, ya abandonaba la carrera definitivamente. José Luis Cuerda había visto Himenóptero, le había apoyado con Luna y le hizo una promesa: producir su primer largometraje, Tesis. Amenábar sólo tenía 21 años. Lo que vino después ya es la historia conocida. 


\section{Análisis del cine de Amenábar}

Alejandro Amenábar ha presumido en multitud de ocasiones de sus dotes como músico. Es cierto que es un buen creador y hay que reconocerle la tarea de haber compuesto las partituras de todas sus películas. De hecho, ha llegado a afirmar que podría haber sido músico en lugar de director de cine.

España necesitaba un director de cine como él: joven, fresco, ingenuo, inocente, pero gran conocedor del cine. Todas esas facetas la reúne Amenábar a la hora de sentarse en su butaca y gritar "jacción!". Su mayor logro está en proponer cosas nuevas, mezclando elementos del pasado, guiones inteligentes, buenas interpretaciones y una concepción del manejo de la cámara, de la luz y del sonido muy cuidadosa. Eso hace que guste al público, precisamente porque dirige pensando en el público. Es algo que pocos directores hacen hoy en día. Los autores consagrados muchas veces se olvidan del espectador, simplemente cuentan historias que a ellos les apetece contar.

Todo ese afán por agradar no debe ser entendido como una falta de calidad. No estamos hablando de un autor que buscara simplemente la fama o las grandes masas de público acudiendo a las salas de cine. Lo cierto es que eso es difícil de conseguir en España, de todas formas. Pero Amenábar va más allá con un cine inteligente y a la vez entretenido. De ahí que, al principio, gracias a Tesis o Abre los ojos, se dijera que su cine estaba hecho "a la americana". Sin embargo, él está un paso por delante de esa pauta americana del espectáculo y del show business. Cree en un cine de calidad, que también puede ser estadounidense, y que guste, que entretenga y que al mismo tiempo, esté bien hecho. Hace un cine digerido, pensado y reflexionado, un cine que a él mismo le gustaría ver como espectador. Y para ello, su mejor arma es utilizar los filmes que ha visto en el pasado. 
Por eso sus películas son cine de género. Lleva a la gente al cine y gusta al público y a la crítica. El director ha confesado que: "No me he propuesto inventar nada. Sólo pretendo mezclar elementos tratando de generar un producto nuevo" (Sempere, 2000, p. 37). La historia del celuloide ya ha demostrado sobradamente que historias y tramas hay pocas. La diferencia está en el punto de vista, en el enfoque, en cómo lo sepa contar uno u otro director. Amenábar le encontró nuevas opciones a cosas que ya se habían hecho. Incluso Mar adentro, que supone un punto de giro en su filmografía, busca también el entretenimiento detrás de la emoción. No se puede cargar al espectador con 120 minutos de drama. Hay que hacerle reír, romper la tensión, hacer que no pierda el hilo ni se sienta agobiado en la butaca. El director, como cinéfilo antes que creador, lo sabe y lo lleva a cabo. Es envidiable que sepa aunar con tal maestría esparcimiento y conocimiento de la técnica.

Por todo ello, se puede decir que Amenábar es director de cine. $Y$ es director antes que músico, montador, o actor. Porque conoce el lenguaje cinematográfico. Sabe cómo utilizar las cámaras para crear una historia. Domina la técnica de crear tensión y en su última película, ha demostrado que también sabe emocionar. Ha pasado del thriller, la ciencia ficción y el terror, hasta llegar al melodrama. $Y$ en cada una de sus cuatro películas ha sabido mantener el tono apropiado, conjugando los distintos elementos según las imágenes lo requerían. Además, es autor con mayúsculas, ya que ve la película desde el guión y escribiéndolo, compone la música y empieza a pensar en los planos. Ha pasado de ser director, como mero oficio, a intentar abarcar todos los campos artísticos para hacer la película absolutamente suya.

\section{Amenábar como guionista}

Muchos grandes directores de cine de la historia han sido simplemente directores. Dirigían y contaban historias escritas por otros. De esta forma, es normal que la película concebida por el guionista fuera diferente a la que creaba el director. Lo extraño está en encontrar una persona que sea guionista y director al mismo tiempo. 
Hay que atreverse a serlo, porque es una tarea difícil y puedes caer en errores que no se producirían compartiendo el trabajo con otra persona. Alejandro Amenábar es uno de esos atrevidos. Ha podido escribir sus películas y dirigirlas. Es cierto que, a pesar de su talento, ha tenido mucha suerte, porque pocos principiantes han tenido oportunidades parecidas. Pero lo sorprendente, además de la fortuna o la buena estrella, es su calidad en los dos ámbitos. Porque la parte complicada de una película es crearla, desde la primera palabra, la primera escena, sabiendo qué quieres decir y qué quieres transmitir. La tarea del director viene después. Lo difícil es partir de cero, enfrentarse al papel.

Por todo ello, Amenábar destaca también como guionista. En este punto hay que hacer una queja, porque pocas veces se habla de Mateo Gil, el coguionista. Apuntes aparte, Amenábar sabe escribir y crear historias. Ha creado tres historias nuevas y originales. Mar adentro no es nueva, pero ha buscado una manera personal de tratarla. Todos sus guiones son inteligentes y desde las normas clásicas del buen guionista, cumple todo lo exigible: tienen presentación, nudo y desenlace, tres actos separados por sus respectivos puntos de giro, diálogos bien pensados, tratados y colocados dentro de la historia, y clímax y anticlímax apropiados. Hay que destacar los arranques, siempre muy válidos, porque son honestos y dan el tono o el estilo de la película. El problema llega cuando se abusa del virtuosismo o se alarga la historia en el tiempo.

Por ejemplo, Tesis tiene un clímax excesivamente largo. Después de la muerte de Castro, parece que va a terminar la película. Pero la protagonista va a casa de Bosco, el verdadero malvado, y se produce otro clímax. Abre los ojos abusa de los puntos de giro. Presenta la historia, mete un golpe de efecto y la vuelve a presentar, desconcertando al espectador. Hay tantas idas y venidas que es normal que el público no entendiera bien el final de la película. Lo peor que le puede pasar a un director de cine es que tenga que explicar su película al público y Alejandro Amenábar lo tuvo que hacer en este caso. Sobre el guión, estaba claro que la última 
voz en off es la de una enfermera que despierta a César en el año 2114. Sin embargo, a nadie le quedaba claro viendo la película. El director se sorprendía, en lugar de reconocer que ha "engañado" demasiado al espectador. La confusión ha crecido hasta ser incontrolable. Debería haber cuidado más los puntos de giro y no abusar tanto de dar pistas falsas y verdaderas entremezcladas, cuando sólo algunos flashbacks, ya al final, daban las claves de lo que estaba ocurriendo. Eso hace que la película esté demasiado dilatada y no haya un arco argumental definido. Va y vuelve hasta dar la solución y el público, al final, ya no sabe qué creer.

De todas formas, Amenábar es un buen guionista. Sabe presentar la historia y dosificar la información haciendo que cada diálogo esté en su sito y no sobre (excepto alguno eliminado en Tesis). Esto deja dilucidar un buen sentido del ritmo y del conocimiento de la técnica del guión. Además le gusta sorprender, contar algo que había mantenido oculto durante toda la película. En Tesis, el misterio es la identidad del asesino. Juega con ello haciendo pensar, en cierto momento, que el asesino es Chema y gira en el final, mostrando que el malo era Bosco. En Abre los ojos, el espectador intenta descubrir, durante dos horas, si César ha matado de verdad a alguien, si está soñando o si está congelado; y no lo sabe hasta el final. Mientras, en Los otros hay unidades parecidas. La situación nos dice que algo raro ocurre en esa casa. Pero el misterio se desvela en la secuencia final, con una buena sorpresa, de las que le gustan a Amenábar. $Y$ en Mar adentro, como el final era conocido, Amenábar busca otro misterio en el personaje de Julia. El espectador ve desde el principio que tiene ocultas razones para implicarse en el caso. Pero el guionista guarda otro golpe de efecto hasta que avance más la historia: su enfermedad degenerativa.

Todos estos aspectos son buena prueba de que Alejandro Amenábar es un buen conocedor de las reglas clásicas del guión. Plantea la película con presentación, nudo, desenlace, arranques bien pensados y clímax que suelen llevar a una gran sorpresa final. La excepción es Mar adentro, pero ahí jugaba con el golpe de efecto 
de la enfermedad degenerativa de Julia. Su único error es dilatar demasiado la historia hacia el final o introducir demasiados puntos de giro como le ocurrió en Abre los ojos. Sin embargo, desde Tesis se ha visto una evolución y una maduración, al saber escribir guiones más simples y ascéticos que eliminaran partes sobrantes.

\section{Del suspense al drama. Los géneros en Amenábar}

Tesis, Abre los ojos y Los otros se desarrollaron entre el thriller, la ciencia ficción y el misterio-terror, respectivamente. Hasta ahí, Amenábar se mostró con un mago del suspense y muchos le apodaron como "el discípulo de Hitchcock". Incluso, sus tres cortometrajes, La cabeza, Himenóptero y Luna, hablaban de un director magnífico a la hora de crear tensión, incertidumbre o terror sin enseñar explícitamente nada que fuera terrorífico. El guión, las imágenes y las interpretaciones hacían pensar que Amenábar se quedaría en esa línea. Faltaba por llegar Mar adentro, un melodrama. Pero hasta entonces, de este director esperábamos sólo miedo, suspense.

Si nos quedamos en sus tres primeras películas, veremos en ellas a un director amante del género, efectivamente influido por Hitchcock y por Agatha Christie (según confiesa él mismo). Se nota que a Amenábar le gusta ese género. Lo manejaba a su antojo, mezclando thriller, persecuciones, violencia, pesadillas, espíritus, o fantasmas. Una película bebía de la anterior. Por eso, sus tres primeros trabajos funcionan a modo de vasos comunicantes.

Por ejemplo, Los otros heredó de Tesis la magia terrorífica de lo que no se muestra, aquello que da miedo estando fuera de campo, sin que el espectador pueda percibirlo directamente. Las dos películas asustaban, aterraban, jugaban con lo desconocido. En Tesis no aparece ninguna escena de un snuff movie, pero el espectador no se atreve a mirar, aunque la curiosidad le haga desearlo profundamente. $Y$ en Los otros parece que hay fantasmas porque abren y cierran las puertas, tocan el piano y asustan a los niños. Pero en ningún momento aparecen en 
la pantalla. Sin embargo, el espectador teme su aparición durante casi dos horas de metraje. Por otra parte, Himenóptero es la semilla de Tesis, con el mismo Bosco ensimismado y paranoico con la idea de la muerte, curioso, febril mirón a través de su cámara. Y la joven conductora de Luna es una primera Nuria, de Abre los ojos, la misma chica, el mismo personaje enigmático, peligroso, pero aún sin perfilar. Todos estos apuntes hacían presagiar que a Amenábar le gustaba la intriga, lo secreto, el terror a la vieja usanza. Quería engatusar, obsesionar y asustar al espectador, aunando lo comercial con un estilo muy personal.

Quizá, parte de ese amor por lo misterioso es fruto de su propia vida. En multitud de ocasiones, ha manifestado que, siendo un niño, no podía estar solo o en la oscuridad. Los otros refleja muchos de esas desconfianzas infantiles. Él mismo se refería así al respecto:

"Aquellos miedos eran típicamente infantiles. Tenía miedo de los fantasmas $y$, como mi hermano quedó sonámbulo después de un accidente, esa circunstancia también daba bastante juego. Lo que sí he consumido, y no lo voy a negar, es mucha literatura de misterio: he debido de leerme todas las novelas de Agatha Christie" (Heredero, 1987, pág. 86).

Unido a ese suspense siempre hay un juego, una incógnita. El suspense se basa siempre en la duda sobre qué ocurrirá, si el protagonista conseguirá o no resolver el conflicto. En Amenábar siempre está presente ese aprieto, esa incógnita, esa pregunta sobre "¿qué pasará?". En Tesis había que descubrir a un asesino. En Abre los ojos, había que descubrir al propio César. Y en Los otros, había que averiguar quiénes eran "los otros", los espíritus. Eso es lo que mantiene la atención del espectador, lo que motiva su deseo de querer llegar hasta el final de la película, el aliciente para seguir adelante. Aparte queda Mar adentro. Es un giro en su trayectoria, en lo que se refiere a géneros cinematográficos. Supone el paso del 
suspense al melodrama, tal como lo entendía Douglas Sirk, el gran maestro del género. El mismo Amenábar lo define así: "Mar adentro es un melodrama, pero con mucho humor. Un melodrama en el que también te ríes mucho. Tiene mucho del género porque me ha gustado mucho desde niño" (Sempere, 2004, pág. 47).

La conclusión es que Amenábar es un verdadero amante del suspense, del misterio antiguo, de los finales sorprendentes de Hitchcock y Agatha Christie. Le gusta asustar al espectador, encerrarle en una atmósfera densa y llevarle al deseo de querer ver toda la película para resolver el misterio. Mar adentro es la excepción, porque es un melodrama. Aunque también se confiesa amante de este género, en contra de lo que nos había hecho pensar hasta su estreno. Así que hay que esperar más películas para decidir si el género que domina es el de la intriga o el del drama. Hasta ahora, se ha movido mejor entre el suspense, pero como amante de éste, siempre guarda una sorpresa.

\section{La cámara de Amenábar. Encuadres, angulaciones, fuera de campo}

Amenábar fue el operador de cámara de sus tres largometrajes y en sus películas se ve claramente ese afán por mirar y registrar las imágenes tal como las había concebido en su mente. Esta idea va muy unida a su perfeccionismo en la planificación, ya explicado anteriormente, y no se pueden exponer por separado. Por eso hay que recordar que a este director le encanta implicar al espectador, le gusta meterle y adentrarle en la película, lograr la complicidad del público. La cámara debe ser también compinche a la hora de conseguir este objetivo. Para ello, recurre a narrar siempre en primera persona, a contar la historia desde el protagonista, colocando la cámara en un plano subjetivo o "casi subjetivo", justo al lado de la mirada del personaje. En Tesis, el espectador va a ver lo mismo que vea Ángela y los dos se quedan sin ver el cadáver del metro o las imágenes del vídeo de Figueroa. Y 
en Abre los ojos, el espectador se siente igual de engañado que César, porque ve el mismo mundo que ve él y siente que no puede ser el real.

Para conseguir ese efecto, recurre a muchos primerísimos planos en los que la pantalla es cubierta por la mirada del personaje. Le importa mucho el poder de lo visual, lo que el ojo ve o no puede ver, porque es lo mismo que va advertir el público. Esa contemplación ayuda a entrar en la psicología del personaje. Refuerza el miedo de Ángela en Tesis, la paranoia de César en Abre los ojos y el terror de Grace en Los otros. Sin esos planos cortos, las películas de Amenábar no podrían ser lo mismo, perderían fuerza y dramatismo. Lo importante es la mirada, el rostro, su gesto y la profundidad de campo disminuye hasta dejar borroso y empastar lo que hay detrás.

Es un momento de intimidad entre el espectador y el personaje. Van a compartir una misma turbación y no importa el alrededor. La fuerza está precisamente en esos ojos o en esa cara. Incluso la mirada de Ramón Sampedro, desde la cama, o la mirada de Julia, pueden mostrar todo su dolor interior, sus miedos, sus fantasmas, lo que han guardado para sí durante años. Amenábar hablaba justamente, en un entrevista, del gusto que siente por los primeros planos y su carga emocional: "Lo más importante son las caras y no el aire que tengamos por arriba o por debajo de los rostros. El cine americano tiende a cortar por arriba y nosotros, en cambio, seguimos dejando mucho aire en casi todos los planos" (Heredero, 1997, pág. 97).

Otro elemento muy característico en la cámara de Amenábar es el contrapicado. Todas sus películas utilizan, en casi todos los planos, un ligero contrapicado para registrar a sus protagonistas. Fue algo que comenzó a hacer en Tesis. Pero el efecto se repite en Abre los ojos y en Los otros. Incluso en Mar adentro, la cámara está algo contrapicada, por debajo de la barbilla de Ramón. Sólo así puede dar poder a sus personajes, capacidad para decidir qué hacer con sus vidas. Les muestra como seres humanos, no como héroes, con sus miedos y sus defectos. Son personas 
normales, como cualquiera de nosotros, y el director no les puede aislar ni hacerlos lejanos, porque al espectador no le interesaría la historia, no se involucraría en ella. El propio Amenábar reconoce el uso y abuso de este contrapicado. Pero él prefiere decir que la invención no es suya y se lo atribuye a uno de sus maestros: Steven Spielberg. De ahí, que lo llame "escorzo spielbergiano".

Todo esto nos hace ver que aprendió a usar la cámara antes de crear historias. Concibe la película pensándola en encuadres y en música. Esto hace que tenga un estilo visual muy definido y manifiesto en sus cuatro largometrajes, desde Tesis a Mar adentro. Le gusta implicar al espectador, huir del narrador omnisciente, contar la historia en primera persona con un plano subjetivo. Aunque él prefiere llamarlo "casi subjetivo", porque a veces, la cámara se pone justo al lado de la mirada del protagonista o un poco detrás de él. De ahí nace también la importancia de los primeros planos, sin aire, que simplemente pretenden enmarcar una mirada y transmitir toda la tensión y emoción del personaje, desde el miedo de Ángela a la pesadumbre de Sampedro. Además une todos estos recursos a un continuo, pero ligero contrapicado para mostrar a sus protagonistas. La cámara se sitúa más abajo de su posición habitual cuando pretende no captar lo que el personaje está viendo. Es una manera de hacerlo más humano, aunque el invento fue de Spielberg y por eso, Amenábar prefiere llamarlo el "escorzo spielbergiano".

\section{Sentido del ritmo y dosificación de la información}

Como todo buen director de cine de suspense, Amenábar cuida el ritmo de sus películas. Sabe cómo escribir el guión para ganarse la confianza del público desde el principio, gracias al arranque y a la presentación de los personajes. Después, va desarrollando poco a poco la historia, en su justa medida, llevando al público por donde quiere. Decía que el thriller es la suma matemática de una serie de elementos y el éxito sólo está en saberlos mezclar en su justa medida. Por eso, Tesis mantiene la tensión de principio a fin. Por la misma razón, el espectador duda hasta el final en 
Abre los ojos y en Los otros. Y por ello, el público de Mar adentro se emociona, aunque sepa a priori que Sampedro se va a quitar la vida. La razón es que hay un deseo de saber más, de querer avanzar hacia delante; lo que impide dejar la película a medias. Sabe cuándo tiene que dar una pista, cuándo debe dar el punto de giro, para que el espectador se sorprenda al ver lo que no esperaba, jugando con la contención, algo que es realmente envidiable. Dominándose a sí mismo, llega a la sorpresa final.

Por estos argumentos, se puede afirmar que Amenábar consigue embaucar al espectador. Le lleva por donde quiere sin que se dé cuenta. Le hace sentirse protagonista de la historia, cómplice e implicado, porque está a la misma altura que los personajes y dispone de la misma información. Sabe lo mismo que ellos saben e irán descubriendo los idénticos misterios al mismo tiempo. Así se logra la complicidad, con tranquilidad, con contención, sin abusar de la confianza del espectador, dándole justamente lo que necesita, nunca más ni menos, porque se aburriría o sabría ir directamente, sin ayuda del director, hasta el final. En ese caso, no habría sorpresa y la película fallaría.

Así que lo más destacable de Amenábar en este aspecto es su contención. Sabe dar al espectador la información oportuna, implicándole, porque está a la misma altura que el personaje y se sienten igual de indefensos. Consigue una complicidad impresionante y necesaria en toda buena película. Nunca dice más de lo necesario. Los puntos de giro llegarán en su momento apropiado. El director marca el tempo, no el espectador. Y el final será siempre sorprendente. Mientras, el espectador no se dará cuenta de que el director le ha manejado a su antojo, introduciéndole en la historia, simplemente por su contención a la hora de informarle. Ahí está parte del éxito de Tesis, Abre los ojos y Los otros. 


\section{Sentido del tiempo. Secuencias y escenas. Formas de paso y recursos temporales}

El sentido del ritmo y la dosificación de la información van muy unidos al uso del tiempo cinematográfico que emplea Alejandro Amenábar. De la misma manera que dosifica la información, gradúa los tiempos. Ambos van acompasados. No importa la duración total de la acción, porque no es algo claro ni relevante en sus películas. Lo importante es cuándo dar la información y los puntos de giro dentro del tiempo de la película de dos horas de metraje. Durante esos ciento veinte minutos, el director cuenta una historia, la desarrolla y sorprende con un final. Lo importante es conseguir que la narración no resulte larga ni tediosa para el público, sino que sea un tiempo aprovechado y disfrutado. Porque Amenábar cree en el entretenimiento. Por eso no es importante decir cuántos días tarda Ángela en encontrar al asesino, o qué tiempo pasa en la realidad o en sueños César. Lo importante es la historia, el tema, el fondo, lo que se cuenta, no en qué tiempo lo enmarcas. Sí es cierto, que Tesis, por su ingenuidad y por ser ópera prima, se alarga demasiado hacia el final y podría haber resuelto la historia en menos minutos. Pero es una crítica pequeña para la calidad general de toda la película.

Sin embargo, hay que decir en contra de estas afirmaciones, que a Amenábar le encanta utilizar ciertos recursos temporales para volver al pasado, nunca al futuro. De ahí que se puedan encontrar fundidos en negro y flashbacks en todas sus películas. Esos recursos sirven para unificar las historia, darlas sentido en el presente y relación con algo ya ocurrido. Por ejemplo, Abre los ojos no se entendería sin los flashbacks finales que hablan del contrato de criogenización y del suicidio de César. La única alusión al futuro es la voz en off de la enfermera que despertará a César un siglo y medio después.

Resumiendo, Amenábar sabe utilizar los tiempos acompasándolos con la dosificación de la información. Conoce cómo distribuir la información a lo largo del metraje, 
logrando la atención plena y continua del espectador. Como ayuda, pero en pocas ocasiones, recurre a flashbacks que nos devuelven al pasado, como el suicido de César o las imágenes de Ramón al tirarse a la poza. Es una manera de unificar la historia y hacer que el espectador pueda entender el presente de los personajes, nunca adivinar su futuro; por eso no hay flashforwards.

\section{La música y el silencio: la banda sonora. Amenábar como músico}

Uno de los rasgos más geniales de Alejandro Amenábar es que ha compuesto las partituras de las bandas sonoras de sus películas. Es algo envidiable, porque le define como autor en mayúsculas, ya que concibe la historia y la música mientras escribe el guión. Eso hace que la música de sus películas siempre sea acorde con el tono del filme. Tesis, Abre los ojos, Los otros y Mar adentro tienen sus propias partituras y no podrían funcionar igual de bien en otra película.

Lo reseñable no es sólo la calidad de la banda sonora, sino su uso dentro de la película. Aquí, Amenábar se vuelve a mostrar contenido, igual que le ocurría con la dosificación de la información. Porque cuida las notas y su inclusión en cada plano, desde el segundo oportuno en el que deben empezar a sonar, hasta el momento en el que deben apagarse. Un buen ejemplo es la escena de Abre los ojos en la Gran Vía. César oye su despertador, se despierta, se asea, se viste, coge su coche y sale del garaje para recoger a su amigo Pelayo. Hasta aquí, el director sólo introduce sonidos de ambiente y la música no empieza a sonar hasta que César se ve a sí mismo solo, en la Gran Vía de Madrid, totalmente desierta.

Por otra parte, esta contención le lleva a no saturar con la música, como suele ocurrir en otras películas del género de suspense. Nunca introduce una melodía para una secuencia entera, sino que la guarda para una serie de planos determinados. Para cubrir esos tiempos sin música, recurre al silencio, al ambiente, a la respiración 
del protagonista. Y en el momento justo, o de mayor carga dramática, la música empieza a sonar. Dentro de este punto, hay que citar un recurso curioso de Los otros que, por el contrario, no utiliza sonidos de ambiente. Los protagonistas están muertos y ya no viven en este mundo, por lo que no se escucha el aire, los pájaros, las gaviotas o el ruido del mar. Estos sonidos los reserva Amenábar para el final, para el mundo de los vivos, cuando Grace ya ha descubierto su situación real y la nueva familia abandona su casa.

Es sorprendente que alguien sin conocimientos de armonía o de composición maneje la música de esta forma. Parte de esos conocimientos pueden estar en un buen oído y en unas buenas influencias, porque Amenábar siempre se ha confesado admirador de músicos clásicos o de compositores de música de cine como John Williams. En una entrevista, confesaba que su proceso de componer era tan simple y natural como lo fue su aprendizaje: "De oído. Yo compongo de oído. La verdad es que la música siempre me gustó y si de niño la hubiera estudiado, es probable que ahora no fuera director, sino músico de cine"(Heredero, 1997, pág. 94).

Quizás, estos conocimientos tan precoces le han llevado a ser un músico poco tópico y a saber elegir los temas cuando eran apropiados. Por eso sorprende que recurriera al Nessum dorma, del Turandot de Puccini o al Agnus dei, de Samuel Barber, porque son obras poco conocidas. Sin embargo, encajaban intachablemente en Mar adentro. De esta misma película también hay que especificar otro aspecto que no se había dado en la filmografía anterior. Es el cambio de la música de un personaje a otro. En las tres películas que la preceden, la música mantenía un tono parecido y se utilizaban los mismos instrumentos. Sin embargo, en Mar adentro, Rosa es acompañada de una música celta, Julia de música clásica sinfónica y Ramón, de una mezcla de las dos anteriores.

Amenábar es director y compositor, porque crea la historia pensando ya en la música. Escribe sus guiones a la vez que compone sus partituras. Sabe qué estilo y 
qué instrumentos son acordes con el tono de la película. Por eso no duda en cambiarla, según la escena o el personaje lo requiera. $Y$ se muestra contenido, pausado, cuidadoso a la hora de enlazarlos con la imagen. Eso le lleva a no querer saturar ni henchir. Pretende huir de esa manía tan inconfundiblemente americana y jamás utiliza la música en secuencias enteras. Prefiere reservarla para momentos 0 planos puntuales, de mayor carga dramática. Lo esencial es recrear un clima, ambientar, dramatizar, no distraer al espectador. El público no se irá de la sala tarareando la canción, pero se emocionará recreando una escena con una música que le acompañaba intrínseca y exclusivamente.

\section{Fotografía. Uso de la luz y cromatismo}

Cada una de sus películas tiene una luz muy marcada, nunca parecida al resto de los filmes. Esto es necesario porque cada una de las historias se desarrolla en un entorno diferente y la fuerza de los espacios marca profundamente la luz que hay en ellos. Esta maestría se debe especialmente a Javier Aguirresarobe, que ha trabajado con Amenábar en sus dos últimos trabajos. Esto no quiere decir que la fotografía fuera descuidada en los trabajos anteriores, donde el iluminador era Hans Burmann.

Para hablar de esa fotografía hay que referirse a cada una de sus obras. En Luna, la fotografía está marcada por una profunda oscuridad. Toda la acción se desarrolla por la noche, en pleno desierto de asfalto. Sólo las caras de los protagonistas están levemente iluminadas, mientras discuten en el coche. Lo importante son sus gestos y sus palabras. El entorno y sus ropas no son indispensables, por lo que la luz se concentra en ellos, mostrándoles como personajes enigmáticos, incomprensibles, peligrosos.

Por otra parte, Tesis recurre a una luz más natural. La fuerza dramática está en la interpretación de los actores, la música y la dosificación de la información. Así que el único recurso llamativo son los contrastes entre la fría facultad, la tenebrosa casa de 
Chema y el cálido hogar de Ángela. Son lugares absolutamente distintos, donde la vida es de diferentes maneras, y la luz tiene que mostrarlo. Incluso el clímax, en casa de Bosco, se desarrolla en la negrura, porque él mismo es un personaje oscuro. La lluvia colabora y hace que la noche sea tenebrosa. Para colmarlo, se funden los plomos. Es el escenario idóneo para que se cometa un asesinato y se resuelva el misterio. Por ello, el final, el epílogo en el hospital, es completamente distinto al resto de la película. Chema y Ángela han descubierto al asesino, han salido de ese túnel del arranque y son nuevas personas. De hecho, se apunta una posible relación entre ellos. Por esta razón, la claridad del hospital no se parece a ninguna de las escenas que la habían precedido.

Abre los ojos, en cambio, va más allá porque se desarrolla en un mundo casi de ficción. La mayor parte de la acción se cuenta desde la cárcel. César está encerrado porque ha matado alguien y su tarea, dentro de esa celda claustrofóbica, se reduce a encontrar la solución sobre si ese asesinato fue real o producto de su imaginación. Está saturado, vive en una absoluta pesadilla, deslumbrado por los hechos y también deslumbrado, literalmente, por una fuerte luz irreal. Esos grandes puntos de luz, demasiado penetrantes para el ojo humano, resuenan pasmosamente a algunas imágenes rodadas por Spielberg. Concretamente, y aunque sea posterior, se asemeja a una escena de Minority Report, en la que el personaje de Tom Cruise nos presenta cuál es su trabajo. Ha recogido la primera bola roja del día y ya sabe qué delito se va a cometer. Tendrá lugar en una casa, donde reside un matrimonio. Él va a matar al amante de su mujer, al descubrir que ésta le es infiel. Lo curioso es que están desayunando en la cocina y al fondo, tras ellos, hay una gran luz nívea que parece desprenderse de la calle. Es una fuente de luminiscencia aparentemente natural, pero exagerada. El motivo es que ese homicidio es un delito que ocurrirá en el futuro, un sueño tenido por los gemelos. Es la misma luz onírica de $E T$ y la misma que tomó Amenábar como inspiración para su segundo largometraje. 
Los otros, en cambio, juega con una iluminación dura, de grandes sombras y contrastes. Atenúa el aislamiento de los protagonistas y sus miedos. Nunca hay luz natural. Incluso el exterior está lleno de neblina. Grace parece peligrosa y temerosa, con una mitad de la cara iluminada y la otra, en la absoluta oscuridad. La luz sólo llegará cuando comprenda qué ha hecho y se vayan los vivos. En ese momento, la casa y el jardín sí parecen reales, porque ella ha asumido su error y su castigo de vivir en el limbo para siempre.

Sin embargo, la contraposición llegará con Mar adentro, una película que se desarrolla casi en su totalidad en espacios cerrados, iluminados virtuosamente. Todo en Mar adentro tiene luz. El mejor ejemplo es el cuarto de Ramón, gobernado por la ventana que él mismo define como su única salida al mundo. Fuera está la vida, la luminosidad inaudita. $Y$ el mensaje intenta empujar hacia ese exterior, ser un símbolo de vida, esperanzador; la luz ayuda a conseguirlo.

Estos ejemplos muestran que Amenábar ha sabido rodearse de excelentes directores de fotografía que han entendido perfectamente qué luz debía presidir cada película. Los cuatro filmes son diferentes y por ello, la iluminación siempre es incomparable, desde la oscuridad de Tesis hasta la luz continua de Mar adentro. Es una manera de dar vida al género y a la historia que se está tratando, llegando, si es necesario, a una fuerza surrealista y onírica que recuerda mucho a la fotografía de Spielberg.

\section{Personajes. Estereotipos, individuos similares. De director a psicoanalista}

No es complicado encontrar similitudes entre los personajes que aparecen en todas las películas de Amenábar. Todos ellos son personajes que tienen un problema que marca su vida y existencia. Son individuos que sufren por el hecho de estar vivos, porque no comprenden su existencia. No saben cómo salir de ese mundo. Lo desean febrilmente, pero debe asumir que es complicado de conseguir. Por ejemplo, en 
Himenóptero, los protagonistas están encerrados en un instituto. Se ha confinado ellos mismos, pero es su cosmos propio y se aíslan del exterior.

En Tesis, los personajes viven recluidos en el mundo audiovisual. Habitan en un entorno en el que sólo importan las imágenes. Las noticias y los telediarios son sólo iconografías sobre la pantalla. Y justamente una imagen es la que puede llevar a Ángela y Chema a la muerte. Viven entre la casa y la facultad. Se relacionan poco con los demás y vegetan ante la televisión, consumiendo imágenes. Ese es su único empalme con la realidad. Aunque ella parece ser un poco más inteligente. Desea saber más. Al final, deseará conocer verdaderamente a Chema. Pero ya desde el arranque, no puede reprimir su deseo de mirar. Esa misma aspiración la llevará a ver a Figueroa muerto, con la cinta violenta que le ha provocado el infarto. Por otra parte, Chema está en un paso más adelante y su amor por lo visual roza lo patológico y lo enfermizo. Colecciona cientos de vídeos y tiene una cámara con la que graba a Ángela en secreto, porque está obsesionado con mirarla. A Bosco le ocurre lo mismo, pero llega a ser capaz de matar para captar buenas y macabras imágenes.

César, en Abre los ojos, también está encerrado. Los barrotes son las cárcel y su pesadilla. Durante toda la película, intentará salir de esa subsistencia, con tanta fuerza, que se suicida en dos ocasiones. La primera vez, se quita la vida porque no aguanta en este mundo. Tiene la cara desfigurada, los médicos no pueden recomponérsela y siente que sólo despierta lástima en aquellos que antes le envidiaban y admiraban. Su segundo suicidio también es una vía de escape de la vida, aunque ésta sea un sueño. Quiere desbandarse de la pesadilla y para ello, se tira desde la azotea de la Torre Picasso y es despertado por una enfermera, un siglo y medio más tarde.

Grace también está marcada por su existencia, concretamente por su muerte. Vive en la nada, en el limbo, recluida en una casa. Su mente está atrancada de la misma 
manera. Ha matado a sus hijos para después quitarse la vida, aunque tardará bastante en reconocerlo. Ese delito es el que la trasladará a estar toda la vida deambulando entre la vida y la muerte, encerrada en el mundo de los espíritus. No soportaba su propia vida, pero tendrá que aprender a vivir su nuevo estado, porque éste no tiene subterfugios.

Ramón, en Mar adentro, también quiere morir. Lleva décadas postrado en su cama, a causa del accidente que le dejó parapléjico. Cree que su vida ya no es digna, que su cuerpo le ha conducido a una existencia temida por cualquier ser humano. Por eso desea la defunción, adelantando los acontecimientos naturales y librándose de esa vida. Aparte quedaría la discusión sobre la licitud de su petición.

Todos estos personajes encerrados en inframundos, son, a la vez, paranoicos, inestables, tremendamente emocionales y delirantes. Les mueve el instinto y la imagen, el exterior, el dolor de su existencia. No saben enfrentarse a sus problemas, porque están desbordados y extenuados. Su aislamiento, prefieren no compartirlo ni desahogarse, para encerrarse en sí mismos. Ahí está el germen de que su conflicto crezca y les lleve a desear la muerte. Todo es fruto del tormento interno, de los miedos y fantasmas interiores; de la incomunicación, al fin y al cabo.

Amenábar se revela como un gran psicoanalista. Crea personajes perfectamente dibujados en el plano psicológico. Lo que dicen y hacen es fruto de una filosofía, de un interior que les atormenta. Viven una existencia para ellos insoportable y su fin es salir de ella. Lo que les diferencia es el camino que eligen para ir hacia la luz y el dominante es el suicidio, excepto en Tesis. Quitarse la vida se convierte en una meta para buscar otra existencia y dar tranquilidad a todas las inquietudes. Aparte queda la interpretación moral y ética sobre estas decisiones. Pero lo cierto es que la idea se repite constantemente. César se suicida dos veces, porque no aguanta su físico ni el dolor de su existencia. Grace no asume la muerte ni el desamor de su marido y su orgullo y su miedo a la soledad la llevan a matar a sus hijos, quitándose ella misma 
la vida a continuación. Esa idea de decidir el momento de la muerte por uno mismo, preside toda la película de Mar adentro, en la que Ramón siente que ya no tiene fuerzas para esperar la muerte desde su cama.

\section{Influencias y conclusiones}

Las páginas anteriores han intentado explicar todos los aspectos del cine de Amenábar, llegando a la conclusión de que hay calidad y reflexión detrás de ellos. Otro punto es que guste o no a cada espectador. Sin embargo, esas dotes artísticas innatas siempre van unidas a una parte aprendida y aprehendida. Este principio se cumple en el caso del director chileno-madrileño que, antes de ser director de cine, se define a sí mismo como "cinéfilo". Ante todo, cinéfilo con mayúsculas y amantes de las historias de la pantalla grande. Antonio Sempere (2004, pág. 21) se refería a ello, manifestando que Amenábar siente un "tremendo, desmesurado, casi patológico amor al cine".

Así que el espectador se encuentra ante un cineasta que amó el cine antes de ser creador. Vio todas las películas posibles para su corta edad y revela que sigue haciéndolo, como coleccionista de DVDs. Pero la semilla inicial estaba en un punto muy claro de la historia del cine. Hay que remontarse al pasado, a los comienzos. Allí comienza Amenábar su repaso cinematográfico personal sobre los directores considerados clásicos:

"Es que yo soy muy poco respetuoso con el clasicismo. Para mí, los cineastas clásicos son los que he visto a partir de los años setenta, y no me puedo creer que el buen cine se hiciera únicamente en los cuarenta o en los cincuenta. Una de las mayores decepciones que me he llevado en mi vida ha sido Centauros del desierto (...) Los directores que más me interesan son Orson Welles y Alfred Hitchcock, pero creo que a éste se le ha sobreestimado. Además, 
cuando se dice que en los clásicos lo más importante no es el fondo, sino el cómo lo transmiten, yo no estoy de acuerdo, porque para mí lo esencial es el fondo de lo que se cuenta y si esto es lo que tantas veces se le ha cuestionado a Spielberg, de la misma forma se le puede cuestionar a Ford" (Heredero, 1997, pág. 83).

Inexcusablemente, hay que detenerse en esta reflexión. Habla de Hitchcock y de cómo se le ha valorado, a su juicio, en demasía. Pero Amenábar peca de orgullo porque sus tres primeros largometrajes guardan pequeños y grandes homenajes al cine de Hitchcock. Amenábar no sería el mismo si no hubiera conocido el suspense de la mano de este fallecido director. Especialmente, hay que fijarse en Vértigo. De entre los muertos (1958), para comprobar, de una ojeada, que hay paralelismos palpables con Abre los ojos. Nos encontramos ante un protagonista parecido, confundido, con dos mujeres en su vida. César tiene a Nuria y a Sofía y Scottie cuenta con Judy y Madeleine. Toda la trama partirá de la visión de ese personaje masculino y uno de los misterios que tendrá que resolver versa sobre la identidad de las féminas. Por otra parte, hay otro gran homenaje en la escena final. Amenábar cambia el Hotel Empire por la Torre Picasso. Allí, a César se le aparece Sofía, como ocurría con Judy ante Scottie, y duda sobre quién es ella. La luz la ilumina y la envuelve con la misma intensidad que eligió Hitchcock para Vértigo. Por eso, no se puede negar que el madrileño haya sido influido por este "maestro". A pesar de todo, le gusta ser orgulloso, apostillar, y criticó esta película así, según el testimonio de Diego Moldes: "Amenábar considera que Vértigo tiene dos errores: desvelar el misterio de la verdadera personalidad de Madeleine a mitad del metraje y la carta leída en off por Madeleine y no enviada, que califica de recurso un poco chapucero" (Moldes, 2004, pág. 164).

Alejándose ya de Hitchcock y de la intriga, hay una influencia que Alejandro Amenábar ha confesado sin miramientos. Es la de Steven Spielberg: "Tuve la suerte de poder ver Tiburón en una pantalla grande, cuando tenía siete $u$ ocho años y ya 
me impactó. Spielberg siempre me ha sorprendido y no tanto por su habilidad técnica, como por su capacidad psicológica" (Heredero, 1997, pág. 84). De esa admiración también se pueden encontrar nuevos paralelismos, como los leves contrapicados (el "escorzo spielbergiano"), o la despedida de Ramón y sus familiares en Mar adentro, que se producía de forma similar en ET. Cualquier otro ejemplo volvería a demostrar que Spielberg es un referente de calidad para Amenábar, desde El imperio del so/ hasta Minority Report.

Hablando de calidad, no se podía dejar a un lado el perfeccionismo y la excentricidad de Stanley Kubrick, otro de los maestros de este discípulo aventajado. El joven director se ha referido a él con estas palabras: "Kubrick es alguien que nunca ha dejado de ser riguroso y que siempre me ha parecido moderno. Quizás, su búsqueda de la perfección resulte algo paranoica, pero lo cierto es que siempre sabe dónde colocar la cámara o cuándo tiene que cortar el plano" (Heredero, 1997, p. 84). Sin embargo, le criticó su trabajo de El resplandor, "donde puso todo su potencial expresivo para producir terror, pero no me funcionó como espectador, fundamentalmente por un error de casting en el personaje protagonista que interpreta Jack Nicholson" (Sempere, 2004, pág. 89). Sea como fuere, Amenábar ha heredado de Kubrick su gusto por experimentar con la cámara, colocándola lejos de las posiciones clásicas, inventando nuevos planos, como el plano "casi subjetivo" o el ligero contrapicado. Esa es la única manera de innovar.

Después llegaría James Cameron, del que Amenábar ha imitado la manera de excitar al público y de controlar la intriga:

"Con Cameron lo que sucede es que controla los mecanismos de la emoción y del suspense como muy pocos hoy en día. Si se analizan sus secuencias de acción, cuesta trabajo comprender cómo ha podido concebir tamaña complejidad, sobre todo si se sabe que 
algunas han sido diseñadas y pre-rodadas en vídeo" (Heredero, 1997, pág. 84).

A partir de estas referencias más generales, el espectador puede encontrar similitudes más concretas. Por ejemplo, Amenábar siempre ha hablado de cómo le marcó David Lynch y El hombre elefante (1982). Sin embargo, Abre los ojos guarda inmensos parecidos con Mullholland Drive, del mismo autor, en lo que se refiere a dicotomías entre sueño y realidad. También se pueden encontrar ciertas influencias de Quentin Tarantino y su película Reservoir Dogs (1993). Pero para centrarse en una película en concreto, la más apropiada es $A /$ final de la escalera. De ella ha heredado Amenábar su manera de tratar el suspense y el terror a través de lo implícito, lo que no se ve, lo que está fuera de campo o simplemente, no existe. La recordaba así: "Es una película que tengo muy presente, porque me parece que transmite muy bien lo que entiendo yo por suspense, por terror. Juega mucho con el sonido y la utilización que hace de la música me ha influido no sólo en Tesis, sino también en todos mis cortos"(Heredero, 1997, pág. 103).

Por otra parte, hay que hacer cierta referencia al cine español aunque, lo cierto, es que no se encuentran muchos paralelismos con películas de la misma nacionalidad. No obstante, Alejandro Amenábar siempre repite los mismos títulos cuando le preguntan sobre el cine del país. Calle mayor (1956) de Berlanga, La Tía Tula (1964) de Juan A. Bardem, El sueño del mono loco (1989) de Fernando Trueba y El espíritu de la colmena (1973), de Víctor Erice, son sus favoritas. Esta última la ha calificado de "obra maestra" y le marcó por la importancia de la mirada de la joven Ana Torrent.

A modo de conclusión, se puede afirmar que el cine de Amenábar se ha alimentado y retroalimentado de su cinefilia casi patológica. Ama el cine desde que era un niño y en los grandes maestros, en lugar de la universidad, ha aprendido lo que necesitaba para comenzar a dirigir. Los nombres más destacados son Alfred Hitchcock, Orson 
Welles, Steven Spielberg, James Cameron o Stanley Kubrick, además de directores más actuales como Quentin Tarantino o David Lynch. De la historia del cine español, sin lugar a dudas, elige a Erice. Pero confía en verlo y leerlo todo. Por esta afirmación, también se puede hablar de influencias literarias en Alejandro Amenábar, desde Frankenstein, El fantasma de la ópera, Doctor Jeckyll y Mister Hyde, hasta el mito de Fausto, germen de Abre los ojos. Toda esta cultura muestra que hay un trasfondo, unos cimientos sobre los que construir una nueva manera de crear.

\section{Bibliografía}

HEREDERO, Carlos F. (1997): Espejo de miradas. Entrevistas con nuevos directores del cine español. Festival de Cine de Alcalá de Henares. Madrid.

HEREDERO, Carlos F. (1999): Veinte nuevos directores del cine español. Alianza Editorial. Madrid.

GASCA, Luis (1998): Un siglo de cine español. Planeta. Barcelona.

MOLDES, Diego (2004): La huella de Vértigo. Ediciones JC. Madrid.

SEMPERE, Antonio (2004): Amenábar, Amenábar. Editorial Club Universitario. Alicante.

SEMPERE, Antonio (2000): Cine en las venas. Nuer. Madrid. 